\title{
Antibacterial Activity of Monolayer Graphene Film to Standardised Staphylococcus Aureus Strains
}

\author{
Gabriel GÂJÂIL $\breve{A}^{1 *}$, Iuliana GÂJÂILA $\breve{A}^{1}$, Bogdan TAŞBAC ${ }^{1}$, Andrei AVRAM², Bianca ŢÎNCU², \\ Tiberiu BURINARU ${ }^{2}$ \\ ${ }^{1}$ Department of Preclinical Science. University of Agronomic Sciences and Veterinary Medicine of \\ Bucharest, Faculty of Veterinary Medicine Bucharest, Romania \\ ${ }^{2}$ National Institute for Research and development in Microtechnologies, Bucharest, Romania \\ *corresponding author: imunogg@yahoo.com
}

Bulletin UASVM Veterinary Medicine 75(1)/2018

Print ISSN 1843-5270; Electronic ISSN 1843-5378

doi:10.15835/buasvmcn-vm:003017

\begin{abstract}
Due to its unique, unanimously recognized properties and biocompatibility, graphene has wide potential applications in biology, biomedical science, environmental agriculture and biotechnology. The antibacterial effect of the graphene is presented in a large number of publications. Most studies reported in the specific literature were aimed mainly at understanding the interaction between graphene and graphene-based materials with cells and bacteria. Even so, there are conflicting results in some cases and there are also numerous controversies regarding the antibacterial effect of monolayer graphene film on different types of substrate.

The study is aimed at testing the antibacterial activity of monolayer graphene film on a copper substrate that was covered with a Staphylococcus aureus culture, Gram-positive bacteria recognized for resilience in external environment. The antibacterial activity of the graphene was evaluated via cell-viability test. It has thus been observed that the bacterial suspension's phisical contact with the a large-area graphene produces significant disturbances of the microorganism's vital processes.

This study may provide new insights for the better understanding of antibacterial actions of graphene applied on different substrates and opportunities for biomedical applications.
\end{abstract}

Keywords: antibacterial activity, graphene, Staphylococcus aureus

\section{Introduction}

Nanomaterial interaction with cells is a relatively recent area of research. The ways nanomaterials can interact with living cells depends on morphology, chemistry and physical parameters of the nanomaterials. Several studies on carbon nanomaterials, such as carbon nanotubes, fullerene and graphene, have shown significant and promising antimicrobial activities (Akhavan et al., 2010; Salas et al., 2010).

Graphene, which was first identified in 2004, is a two-dimensional ultra-thin nanomaterial composed only of hybridized-sp ${ }^{2}$ carbon atoms, arranged in a hexagonal structure, similar to that of a honeycomb. It is the first two-dimensional crystalline material ever produced. Owing to its unique properties of two-dimensional structure, high active surface area, mechanical resistance, conductivity, transparency and thermal resistance, graphene has characteristics on which thousands of researchers have been focusing their attention in the last decade via fundamental studies for future applications (Wolf, 2014, Russel et al., 2014; He et al., 2015).

Bioengineering will certainly be an area in which graphene will become an essential element. However, the properties it displays suggest that it could revolutionize this domain in several ways. With graphene's large surface area, high electrical conductivity, thinness and robustness, it would be a good candidate for the rapid and efficient development of bioelectric sensors, such as the ability to monitor glucose, hemoglobin, Cholesterol and even sequencing of DNA. Similarly, due to 


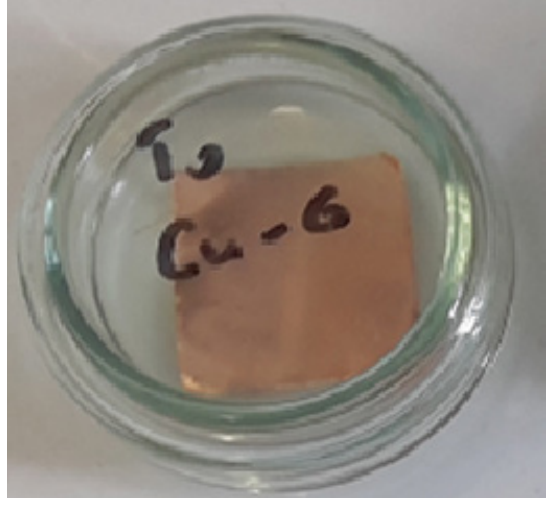

Figure 1. Large-area graphene film

its molecular composition and biocompatibility, graphene could be used in the process of tissue regeneration (Wang et al., 2017).

Most researchers believe that monolayer graphene film can inhibit bacterial proliferation on it's surface, even when the bacteria has all the conditions for optimal growth (Li Jinhua et al., 2014, Kurantowicz et al., 2015, Hegab et al., 2016).

There are varied preparation procedures for obtaining monolayer graphene materials and provide the ability to tune the interaction with bacteria. Therefore there is no a coherency regarding the interaction of bacteria with graphene surfaces (Jastrzebska et al., 2012) so there are conflicting results in some cases and numerous controversies regarding the antibacterial effect of monolayer graphene film on different substrate types (Dellieu et al., 2014).

Most publications focused on antibacterial activity against Gram-negative bacteria, such as Escherichia coli and inhibition percent was determined on their suspensions by Colony Forming Unit counting method (Liu et al., 2011; Tu et al, 2013).

The objective of this experiment was testing the antibacterial activity of the monolayer graphene film against $S$. aureus, a Gram-positive cocci, the causative agent of a variety of diseases ranging from minor skin infections to endocarditis, capable of biofilm formation, which increases its persistence and boosts its levels of antimicrobial resistance (Costerton et al., 1999).

\section{Materials and methods}

The experiment was performed in the Laboratory of Microbiology, Faculty of Veterinary Medicine Bucharest, in collaboration with Labora-

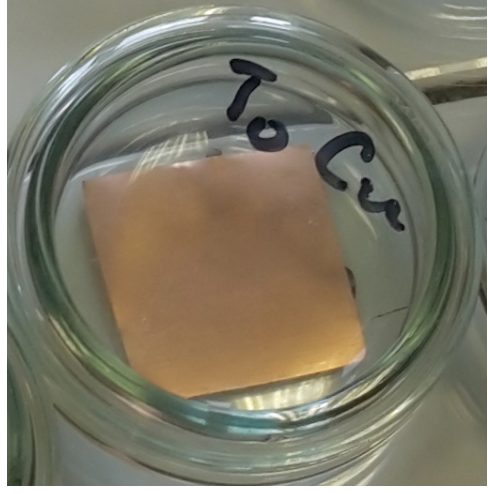

Figure 2. Bare cooper foil

tory for Micro- and Nano- Fluidics, National Institute for R\&D in Microtechnologies, Bucharest.

The Graphene tested. For this experiment, large-area graphene films were applied directly on copper substrates, produced by chemical vapor deposition (CVD). Each foil graphene had a thickness of $35 \mu \mathrm{m}$ and a surface area of $4 \mathrm{~cm}^{2}$ (Figure 1). Bare copper foils were also used, identical from the point of view of initial treatment with those used as substrate for graphene films (Figure 2).

The bacteria used. The antibacterial activity of the monolayer graphene film was tested on the S. aureus ATCC 29213, a Gram-positive bacteria and one of the most commonly used strains in drug research and for quality control. The bacterial strain was kept in the collection of Microbiology Laboratory of the Faculty of Veterinary Medicine Bucharest. S aureus ATCC 29213 were first applied overnight in Columbia Agar at $37^{\circ} \mathrm{C}$ and then harvested at the exponential growth phase. Well isolated colonies from overnight culture were harvested and washed twice to remove residual macromolecules and other growth medium constituents. Then the cells were re-suspended in sterile saline solution. The inoculums was emulsified inside the saline tube and incubated at $37^{\circ} \mathrm{C}$ for $10 \mathrm{~min}$ to adjust the inoculums standard to a $0.5 \mathrm{McF}$ arland (approximately $10^{8} \mathrm{CFU} / \mathrm{ml}$ ).

Antibacterial Activity Evaluation. We evaluated the antibacterial activity of monolayer graphene films by investigating the outcome of $S$. aureus cells physical contact with monolayer graphene films. The metabolic activity of $S$. aureus cells incubated on the graphene surface was measured via cell-viability test: loss of viability was evaluated by the classic colony counting method. 

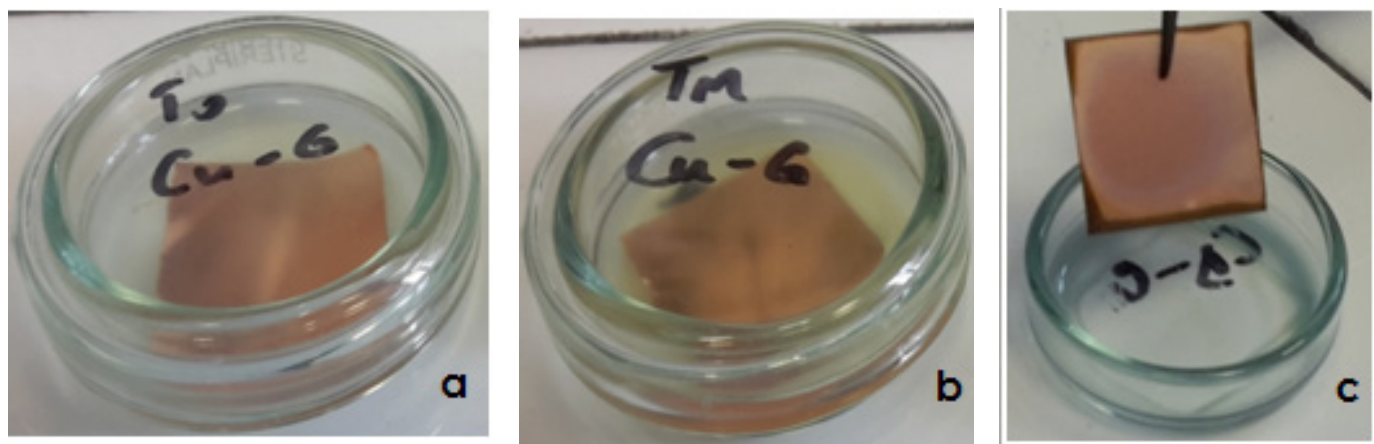

Figure 3. Monolayer graphene film covered with bacterial suspension of $S$. aureus before incubation (a) and after incubation at $37^{\circ} \mathrm{C}$ for $24 \mathrm{~h} \mathrm{(b).} \mathrm{The} \mathrm{graphene} \mathrm{surface} \mathrm{after} \mathrm{collection} \mathrm{of} \mathrm{the} \mathrm{bacterial}$ suspension incubated (c).

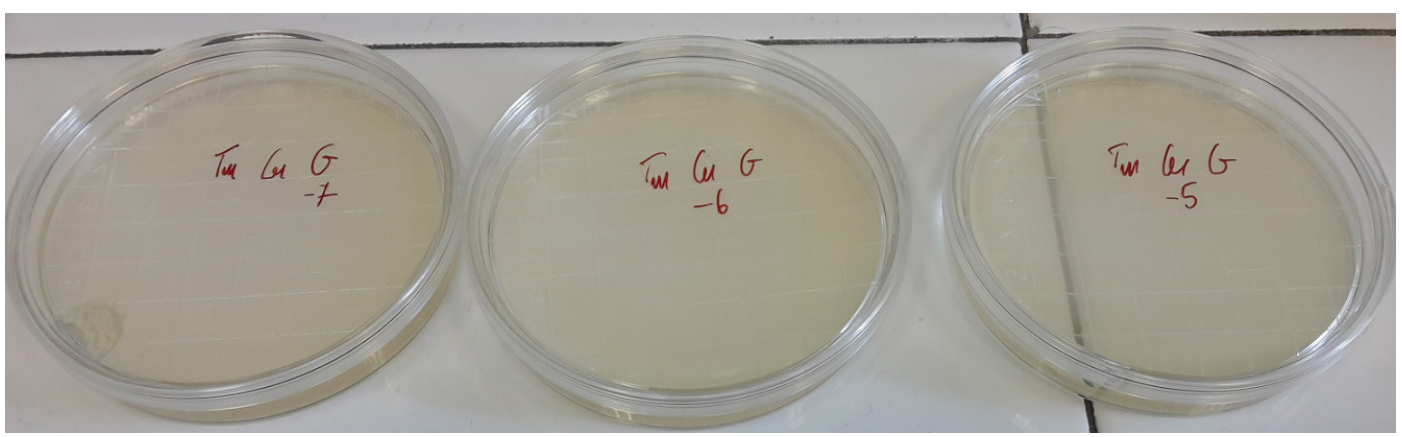

Figure 4. The bacterial suspension dilutions that have been incubated on the graphene film are inoculated on standard agar plates.

Table 1. The colony-forming units (CFU) after being incubated on the different surfaces and their inoculation on standard agar plates

\begin{tabular}{|c|c|c|}
\hline \multirow{2}{*}{ Dilution } & \multicolumn{2}{|c|}{ Surface } \\
\hline & Graphene \& Cooper & Bare Cooper \\
\hline \multirow{4}{*}{ Dilution $10^{5} \mathrm{CFU} / \mathrm{ml}$} & $56 \mathrm{CFU}$ & 140 CFU \\
\hline & $54 \mathrm{CFU}$ & $170 \mathrm{CFU}$ \\
\hline & $59 \mathrm{CFU}$ & $160 \mathrm{CFU}$ \\
\hline & $\gamma=56,33 \mathrm{CFU}$ & $\gamma=156,6$ CFU \\
\hline \multirow{4}{*}{ Dilution $10^{6} \mathrm{CFU} / \mathrm{ml}$} & $21 \mathrm{CFU}$ & $62 \mathrm{CFU}$ \\
\hline & $19 \mathrm{CFU}$ & $170 \mathrm{CFU}$ \\
\hline & $25 \mathrm{CFU}$ & $160 \mathrm{CFU}$ \\
\hline & $\gamma=21,66 \mathrm{CFU}$ & $\gamma=60,66$ CFU \\
\hline \multirow{4}{*}{ Dilution $10^{7} \mathrm{CFU} / \mathrm{ml}$} & $2 \mathrm{CFU}$ & $8 \mathrm{CFU}$ \\
\hline & $0 \mathrm{CFU}$ & $9 \mathrm{CFU}$ \\
\hline & $3 \mathrm{CFU}$ & $11 \mathrm{CFU}$ \\
\hline & $\gamma=1,66$ CFU & $\gamma=9,33$ CFU \\
\hline
\end{tabular}

In order to assess bacterial proliferation on the graphene film $240 \mu \mathrm{l}$ of the inoculum was pipetted onto the surface of monolayer graphene tested. The graphene surface covered with bacterial suspension was incubated at $37^{\circ} \mathrm{C}$ for 24 hours. Subsequent the bacterial suspension, incubated on the graphene surface was collected and serially diluted (Figure 3). $200 \mu \mathrm{l}$ of each dilution were inoculated on standard agar plates (Figure 4). After a re-incubation overnight at $37^{\circ} \mathrm{C}$ the colonyforming units (CFU) were counted. The bacterial viability or the percentage of activated cells was estimated from the ratio of the number of final cells divided by the number of cells at the beginning 


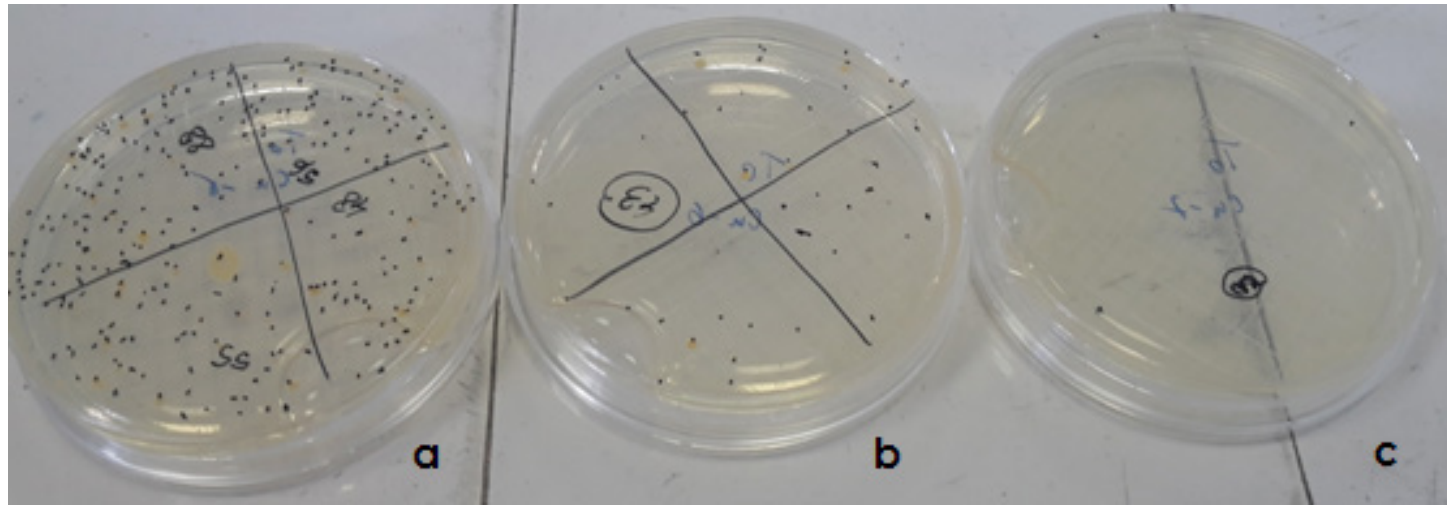

Figure 5. The number of colonies in the Petri dishes corresponding to the dilutions prepared after incubated on the graphene film and inoculated $\left(\mathrm{a}-10^{7} \mathrm{CFU} / \mathrm{ml}, \mathrm{b}-10^{6} \mathrm{CFU} / \mathrm{ml}, \mathrm{c}-10^{5} \mathrm{CFU} / \mathrm{ml}\right)$. The reducing the bacterial viability ( $\mathrm{CFU})$ with increasing dilution.

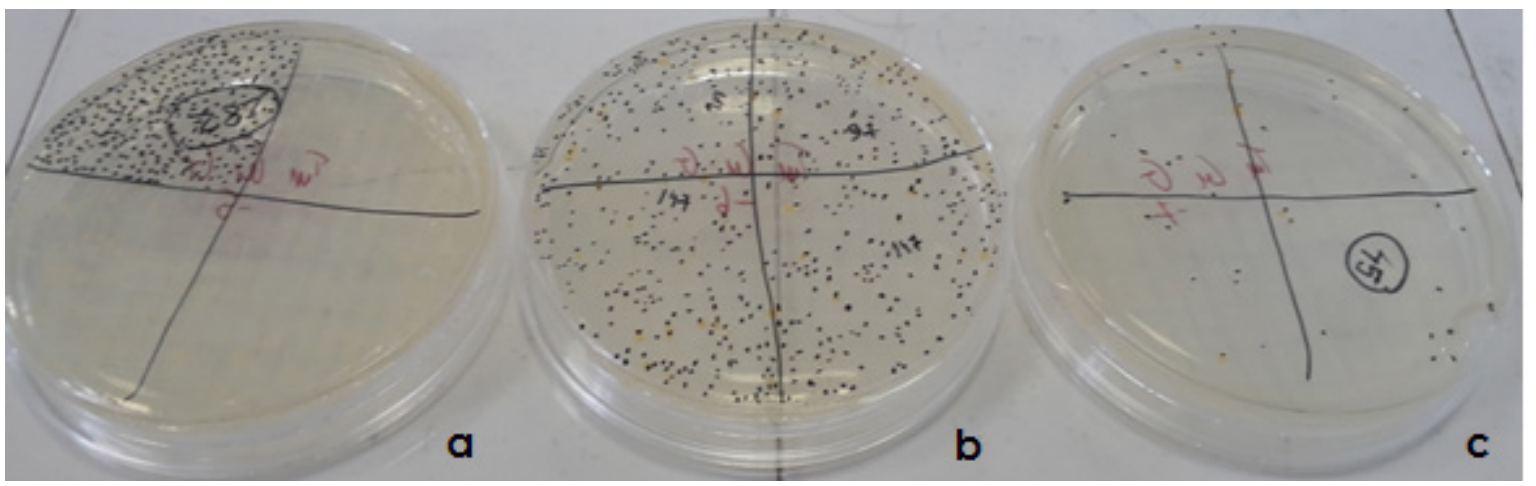

Figure 6. The number of colonies in the Petri dishes corresponding to the dilutions prepared after incubated on the bare cooper foil and inoculated.

of experiments. To eliminate the possibility of interference of cupric ions in the antibacterial activity of graphene, the same protocol was applied and to bare copper foils, uncovered with monolayer graphene film. All treatments were prepared in triplicate and repeated at least in three independent experiments.

\section{Results and discussion}

Colony-forming units (CFU) were counted after preparation of serially dilutions $\left(10^{7} \mathrm{CFU} /\right.$ $\mathrm{ml}, 10^{6} \mathrm{CFU} / \mathrm{ml}, 10^{5} \mathrm{CFU} / \mathrm{ml}$ ) of the bacterial suspension incubated on the graphene surface and their inoculation on standard agar plates (Table 1 and Figure 5). The antibacterial activity of the graphene was proven by the small number of colonies obtained after the final seeding with liquid collected from the monolayer graphene film. In the samples with higher dilution, the bacterial strains tested did not survive (Figure 5, c).
The possible interference of copper ions in the antibacterial activity was ruled out, special tests having proven that no such ions were released. In all tests performed, there was a noticeable difference between the numbers of bacteria that survived the contact with monolayer graphene film compared with the contact with simple copper surface (Figure 6).

\section{Conclusions}

Monolayer graphene film has antibacterial activity, inhibiting the growth of bacteria that comes in contact with it. For S. aureus ATCC 29213, the antibacterial activity of monolayer graphene film on copper substrate was demonstrated during this experiment. The conductive character of graphene may cause the removal of electons from the cytoplasmic membrane of the bacteria, thus blocking the multiplication process. We hope that this result will contribute to the understanding of the antibacterial capabilities of graphene. 
Acknowledgments: This work was supported by Experimental Demonstration Projects PN-IIICERC-CO-PED-2016-0123

\section{References}

1. Akhavan O, Ghaderi E (2010). Toxicity of graphene and graphene oxide nanowalls against bacteria. ACS Nano, 4: 5731-5736.

2. Costerton JW, Stewart PS, Greenberg EP, (1999). Bacterial Biofilms: a common cause of persistent infections. Science, 284: 1318-1322.

3. Crawford RJ, Ivanova EP, Notley SM (2014). Bacterial Interaction with Graphene Particles and Surfaces. In: M. Aliofkhazraei (Ed.), Advance in Graphene Science (Chapter 5, pp. 99-118). Rijeka: InTech.

4. Dellieu L, Lawarée E, Reckinger N, Didembourg C, Letesson J-J, Sarrazin M, Deparis O, Matroule J-Y, Colomer J-F (2015). Do CVD applied graphene films have antibacterial activity on metallic substrates? Carbon, 84: 310-316.

5. He J, Zhu X, Qi Z, Wang C, Mao X, Zhu C, He Z, Li M, Tang $Z$ (2015). Killing dental pathogens using antibacterial graphene oxide. ACS Appl Mater Interfaces, 7: 5605-5611.

6. Hegab HM, El-Mekawy A, Zou L, Mulcahy D, Saint CP, Ginic-Markovic M (2016). The controversial antibacterial activity of graphene-based materials. Carbon, 105: 362376.

7. Jastrzebska AM, Kurtycz P, Olszyna AR (2012). Recent advances in graphene family materials toxicity investigations. J Nanopart Research, 14: 1-21.
8. Kurantowicz N, Sawosz E, Jaworski S, Kutwin M, Strojny B, Wierzbicki M, Szeliga J, Hotowy A, Lipińska L, Koziński R, Jagiełło J, Chwalibog A (2015). Interaction of graphene family materials with Listeria monocytogenes and Salmonella enterica. Nanoscale Res Lett, 10: 23.

9. Li J, Wang G, Zhu H, Zhang M, Zheng X, Di Z, Liu X, Wang $X$ (2014). Antibacterial activity of large-area monolayer film manipulated by charge transfer. Scientific Reports, 4 : 4359.

10. Liu S, Zeng TH, Hofmann M, Burcombe E, Wei J, Jiang R, Kong J, Chen Y (2011). Antibacterial activity of graphite, graphite oxide, graphene oxide, and reduced graphene oxide: membrane and oxidative dtress. ACS Nano, 5: 6971-6780.

11. Salas EC, Sun Z, Luttge A, Tour JM (2010). Reduction of graphene oxide via bacterial respiration, ACS Nano, 4: 4852-4856.

12. Tu Y, Lv M, Xiu P, Huynh T, Zhang M, Castelli M, Liu Z, Huang Q Fan C, Fang H, Zhou R (2013). Destructive extraction of phospholipids from Escherichia coli membranes by graphene nanosheets. Nat Nanotechnol, 8: 594-601.

13. Wang LL, Hu C, Shao LQ (2017). The antimicrobial activity of nanoparticles: present situation and prospects for the future. Int J Nanomedicine, 12: 1227-1249.

14. Wolf, Edward L (2014). Applications of Graphene, an Overview. Springer Briefs in Materials. 